\title{
Effect of Sowing Dates and Wheat Genotypes on Growth, Yield and Production Economics
}

\author{
Manoj Kumar, R. S. Singh* and I. B. Pandey
}

Tirhut College of Agricultue, Dholi, Dr. Rajendra Prasad Central Agricultural University, Bihar, India

*Corresponding author

\section{A B S T R A C T}

\section{Keywords}

Queen of cereals, Wheat, Parameters, Eco-physiological factors

Article Info

Accepted:

04 September 2019

Available Online:

10 October 2019
An experiment was conducted at research farm of Rajendra Agricultural University, Pusa (Samastipur), Bihar during rabi season of 2003-04 with four sowing dates i.e., 27th November, 11th December, 25th December and 8th January along with four test varieties i.e., K 9107, PBW 343, HP 1744 and NW 1014 under split plot design to find out suitable sowing time for newly released wheat varieties under irrigated condition of Bihar and their economics of production. It was found that delay in sowing beyond 11th December drastically reduced the grain yield to the tune of 47.5 and 70.6 per cent, respectively when sown on 25th December and 8th January with respect to normal sowing on 27th November. Among varieties, K 9107 and PBW 343 achieved significantly higher grain yield than HP 1744 and NW 1014 varieties. Net return and B:C ratio were also significantly higher when wheat was sown on 27th November and followed by 11 th December. Beyond 11th December, it registered 334 and 337 per cent decrease in net return/ha. Sowing of wheat on 8th January was found uneconomical. Wheat varieties K 9107 and PBW 343 were found suitable for irrigated condition of Bihar.

\section{Introduction}

Wheat (Triticum aestivum L.), the queen of cereals, is an important crop in the world farming. Globally, wheat occupies over 30 per cent of the area under all food grain crops and serves as an staple food over billions of people in 43 countries.

In Bihar, wheat sowing stretches from mid November to first week of January. Good crop yield depends on a set of eco-physiological factors coupled with the inherent yield capacity of the crop variety. It is a known fact that genetic make-up limits the expression of yield in response to existing environmental conditions.

On the contrary, unfavourable environmental parameters do not allow the full expression of the yielding ability of a variety. Keeping above fact in view the present experiment was 
conducted at research farm of the then Rajendra Agricultural University, Pusa (Samastipur), Bihar.

\section{Materials and Methods}

The field experiment was conducted at research farm of Rajendra Agricultural University, Pusa (Samastipur), Bihar during rabi season of 2003-04. The soil of the experimental plot was silty clay loam in texture, medium in organic carbon $(0.63 \%)$, low in available nitrogen $(247.9 \mathrm{~kg} / \mathrm{ha})$, potash $(128.0 \mathrm{~kg} / \mathrm{ha})$, medium in available phosphorus $(26.80 \mathrm{~kg} / \mathrm{ha})$ with $\mathrm{pH}$ 7.8. The treatment comprised of four sowing dates i.e., $27^{\text {th }}$ November, $11^{\text {th }}$ December, $25^{\text {th }}$ December, and $8^{\text {th }}$ January along with four test varieties i.e., K 9107, PBW 343, HP 1744 and NW 1014. The treatments were replicated thrice under split plot design. The crop was sown $20 \mathrm{~cm}$ apart using $125 \mathrm{~kg}$ seed $/ \mathrm{ha}$. The crop was uniformly fertilized with $120: 60$ : $40 \mathrm{~kg} \mathrm{~N}: \mathrm{P}: \mathrm{K} / \mathrm{ha}$.

\section{Results and Discussion}

The data presented in table 1 had shown significant effect of sowing dates as well as different genotypes on plant height, leaf area index, crop growth rate and number of tillers per metre linear length.

Plant height recorded at harvest under sowing on $27^{\text {th }}$ November was found significantly superior than the plant height under sowing on $25^{\text {th }}$ December, and $8^{\text {th }}$ January but was found at par with the plant height under sowing on $11^{\text {th }}$ December which may be due to more congenial environmental amplitudes that resulted in more cell elongation and hence the plant height. Nainwal and Singh (2000) and Lathwal and Thakrapal (2000) also observed that growth of wheat plant was stunted under late sown condition. Varieties had also significant effect on plant height and significant highest value of $100.27 \mathrm{~cm}$ was recorded by K 9107 and closely followed by NW 1014 and lowest in PBW 343 which may be their genetic features.

Similar effect of dates of sowing was observed on number of tillers per metre linear length. Effect of dates of sowing on leaf area index and crop growth rate was more pronounced. $27^{\text {th }}$ November sown crop proved superiority over other dates of sowing and the values of leaf area index and crop growth rate decreased with further delay in sowing the crop. Different genotypes of wheat did not show much difference with respect to leaf area index. Significant lowest values of crop growth rate and number of tillers per metre linear length were recorded by the variety HP 1744.

The yield attributing characters were found to have better expression in crop sown on $27^{\text {th }}$ November followed closely by $11^{\text {th }}$ December and the value declined drastically with delayed sowing. The crop sown on $27^{\text {th }}$ November produced the highest grain yield which drastically reduced to 47.5 and 70.6 per cent when sowing was delayed to $25^{\text {th }}$ December and $8^{\text {th }}$ January, respectively which might be due to rise in temperature above $15{ }^{\circ} \mathrm{C}$ during grain filling stage in delayed sowing and also due to reduction in duration of grain filling because, grain yield decreases by about 3-4 per cent for each $1^{\circ} \mathrm{C}$ rise in temperature above $15{ }^{\circ} \mathrm{C}$ during grain filling stage (Wardlaw and Wringley, 1994). Varieties had also significant effect on grain yield. Similarly, highest grain yield was obtained in K 9107 which was at par with PBW 343 and significantly higher than HP 1744 and NW 1014. The grain yield of wheat varieties, $\mathrm{K}$ 9107 and PBW 343 reduced drastically when sowing was beyond $25^{\text {th }}$ December. 
Table.1 Effect of sowing dates and different genotypes on plant height, leaf area index, crop growth rate and number of tillers per metre linear length.

\begin{tabular}{|c|c|c|c|c|}
\hline Treatments & $\begin{array}{c}\text { Plant height } \\
\text { at harvest } \\
\text { Date of sowing }\end{array}$ & $\begin{array}{c}\text { Leaf Area } \\
\text { Index (LAI) } \\
\text { at 90 DAS }\end{array}$ & $\begin{array}{c}\text { Crop Growth } \\
\text { Rate (60-90 } \\
\text { DAS) }\end{array}$ & $\begin{array}{c}\text { Number of tillers/ } \\
\text { metre linear length at } \\
\text { harvest }\end{array}$ \\
\hline $\mathbf{2 7}^{\text {th }}$ November, & 93.78 & 3.96 & 3.06 & 65.92 \\
\hline $\mathbf{1 1}^{\text {th }}$ December & 92.19 & 3.74 & 2.49 & 63.08 \\
\hline $\mathbf{2 5}^{\text {th }}$ December & 85.83 & 3.49 & 2.31 & 52.33 \\
\hline $\mathbf{8}^{\text {th }}$ January & 84.00 & 3.24 & 1.20 & 45.83 \\
\hline CD (p=0.05) & 4.02 & 0.21 & 0.39 & 3.83 \\
\hline Varieties : & & & & \\
\hline K 9107 & 100.27 & 3.60 & 1.72 & 58.25 \\
\hline PBW 343 & 79.22 & 3.41 & 1.82 & 55.58 \\
\hline HP 1744 & 81.19 & 3.46 & 1.41 & 53.58 \\
\hline NW 1014 & 95.11 & 3.58 & 1.48 & 59.75 \\
\hline CD (p=0.05) & 4.02 & NS & 0.39 & 3.83 \\
\hline
\end{tabular}

Table.2 Effect of sowing dates and different genotypes on yield, gross return, net return and $\mathrm{B}: \mathrm{C}$ ratio of different wheat genotypes.

\begin{tabular}{|c|c|c|c|c|}
\hline $\begin{array}{c}\text { Treatments } \\
\text { Date of sowing }\end{array}$ & $\begin{array}{c}\text { Grain yield } \\
(\mathbf{q} / \mathbf{h a})\end{array}$ & $\begin{array}{c}\text { Gross return } \\
(\mathbf{R s} / \mathbf{h a})\end{array}$ & $\begin{array}{c}\text { Net return } \\
(\mathbf{R s} / \mathbf{h a})\end{array}$ & B : C Ratio \\
\hline $\mathbf{2 7}^{\text {th }}$ November, & 30.68 & 26579 & 16188 & 1.56 \\
\hline $\mathbf{1 1}^{\text {th }}$ December & 28.29 & 24565 & 14174 & 1.37 \\
\hline $\mathbf{2 5}^{\text {th }}$ December & 16.12 & 14043 & 3653 & 0.35 \\
\hline $\mathbf{8}^{\text {th }}$ January & 8.77 & 768 & $(-) 2709$ & -0.26 \\
\hline CD (p=0.05) & 1.11 & 962 & 1040 & 0.10 \\
\hline Varieties : & & & & \\
\hline K 9107 & 22.39 & 19430 & 9039 & 0.87 \\
\hline PBW 343 & 21.60 & 18764 & 8373 & 0.81 \\
\hline HP 1744 & 19.55 & 17000 & 6610 & 0.64 \\
\hline NW 1014 & 20.33 & 17680 & 7283 & 0.70 \\
\hline CD $(\mathbf{p = 0 . 0 5 )}$ & 1.11 & 962 & 1040 & 0.10 \\
\hline
\end{tabular}

However, The NW 1014 produced maximum grain yield when sowing was delayed to $8^{\text {th }}$ January. Wheat varieties - K9107 and PBW 343 also earned higher net return (Table 2). K 9107 and PBW 343 recorded higher yield under timely sown condition while NW 1014 performed better when sown on $8^{\text {th }}$ January. Gross return, net return and $\mathrm{B}: \mathrm{C}$ ratio follow the same trend to that of grain yield and all these three economic parameters were found significantly superior under $27^{\text {th }}$ November sowing than later delayed sowings. Among varieties, K 9107 showed its superiority over other varieties with respect to gross return, net return and $\mathrm{B}: \mathrm{C}$ ratio. Grain yield of wheat varieties reduced drastically when sowing was done beyond $25^{\text {th }}$ December and hence, sowing of wheat beyond $25^{\text {th }}$ December was not found economical.

\section{References}

Lathwal, O.P. and Thakrapal, S. K. (2000). Performance of wheat varieties sown 
on different dates under rainfed condition. Field Crop abstracts. 2000 53(6): 500.

Nainwal, K. and Singh, M. (2000). Varietal behavior of wheat () to date of sowing under Tarai region of Uttar Pradesh.
Indian J. Agron. 45 (1): 107-113. Wardlaw,I.F. and Wringley, C.W. (1994). Heat tolerance in temperate cereals : An overview. Australian J. Plant Physiology. 21: 695-703.

\section{How to cite this article:}

Manoj Kumar, R. S. Singh and Pandey, I. B. 2019. Effect of Sowing Dates and Wheat Genotypes on Growth, Yield and Production Economics. Int.J.Curr.Microbiol.App.Sci. 8(10): 187-190. doi: https://doi.org/10.20546/ijcmas.2019.810.019 